\title{
МОРФОЛОГІЧНІ ЗМІНИ ПРИ ЕКСПЕРИМЕНТАЛЬНОМУ ГІНГІВІТІ ІЗ ГІПОЕРГІЧНИМ ПЕРЕБІГОМ ЗАПАЛЬНОГО ПРОЦЕСУ
}

\author{
๑Р. О. Древніцька, З. М. Небесна, О. В. Авдєєв, А. Б. Бойків, Б. О. Авдєєв \\ Тернопільський національний медичний університет імені І. Я. Горбачевського МОз України
}

РЕзЮМЕ. Мета - дослідити морфологічні зміни тканин пародонта при експериментальному гінгівіті з гіпоергічним перебігом запального процесу.

Матеріал і методи. Гістологічному дослідженню піддавали альвеолярний відросток із зубами і тканинами пародонта інтактних щурів і щурів з експериментальним гінгівітом. Виготовляли зрізи товщиною 6-7 мкм, які зафарбовували гематоксиліном і еозином.

Результати. Морфологічна картина гінгівіту в гіпоергічній групі характеризувалась не тільки запальними змінами, одночасно з ними розвивалися дистрофічні і регенераторні процеси. Спостерігається виражений акантоз зі збільшенням епідермальних відростків, що $\epsilon$, швидше за все, результатом уповільнення дозрівання та диференціювання епітеліоцитів унаслідок мітостатичної дії циклофосфаміду.

Підтвердженням цього $є$ мала кількість мітозів у клітинах базального шару. В епітелії міжзубних сосочків часто зустрічаються кістоподібні утворення з елементами ороговіння всередині.

Зустрічався паракератоз - порушення процесу ороговіння, коли зернистий шар практично відсутній, а в роговому визначаються клітини з пікнотичними паличкоподібними ядрами.

Висновки. Морфологічними дослідженнями встановлено, що при експериментальному гінгівіті без зміни реактивності організму були наявними деструктивні зміни епітеліального та сполучнотканинного шарів слизової оболонки ясен: набряк, лейкоцитарна інфільтрація у сполучнотканинному шарі; ущільнювалися зернистий та остистий шари епітелію.

Особливістю запального процесу в яснах при його гіпоергічному перебігу була лейкоцитарна інфільтрація як епітелію, так і субепітеліальних тканин, поява акантозу зі збільшенням епідермальних відростків і паракератозу.

КлючовІ слОВА: гінгівіт; перебіг запальної реакції; структурні зміни ясен.

Вступ. Виникнення патологічних змін у тканинах пародонта відбувається за дії ряду екзогенних факторів, зокрема, патогенного впливу мікроорганізмів зубної бляшки та продуктів їх життєдіяльності та загальних факторів, які регулюють метаболізм організму, в тому числі тканин порожнини рота. Водночас, несприятливі екзогенні й ендогенні фактори, які змінюють реактивність організму сучасної людини, є не менш важливими у виникненні, розвитку, перебігу, ризику хронізації патологічного процесу та ефективності лікування захворювань тканин пародонта [1].

Проведені раніше дослідження показують певні відмінності у будові та функціональній активності ясен [2], біохімічних показниках [3] при експериментальному пародонтиті. Водночас цікавим було дослідити морфологічні зміни у тканинах пародонта за експериментального гінгівіту зі зміненим перебігом запальної реакції.

Мета - дослідити морфологічні зміни тканин пародонта при експериментальному гінгівіті з гіпоергічним перебігом запального процесу.

Матеріал і методи дослідження. В експерименті були використані щури-самці віком 5-6 місяців. Експериментальний гінгівіт викликали за допомогою цитостатика циклофосфаміду та місцевого впливу ультразвуку частотою 50 кГц, потужністю випромінювання від 1,0 до 1,2 Вт/см² при експозиції коливань 45 с, торкаю- чись в приясневій ділянці нижнього різця [4] - гіпоергічна група; у другій групі використовували лише вплив ультразвуку у вищевказаній дозі нормергічна група. Гістологічному дослідженню піддавали альвеолярний відросток із зубами і тканинами пародонта 10 інтактних щурів та 20 щурів з експериментальним гінгівітом (норм- і гіпоергічної груп). Блоки нижньої щелепи із зубами и яснами фіксували в 10 \% розчині нейтрального формаліну, декальцинували в 5 \% розчині азотної кислоти. Контроль часу витримки зразків в декальцинувальній рідині проводили шляхом проколювання кістки препарувальною голкою. Після проведення у спиртах висхідної концентрації тканини заливали в целоїдин-парафін. 3 блоків виготовляли зрізи товщиною 6-7 мкм, які зафарбовували гематоксиліном і еозином [5].

Світлооптичне дослідження препаратів проводили під мікроскопом та документували. Препарати ясен фотографували за допомогою мікроскопа MICROmed SEO SCAN і відеокамери Vision CCD Camer з наступним аналізом.

Експерименти на тваринах здійснювали у відповідності до Європейської конвенції із захисту хребетних тварин, яких використовують для дослідних та інших наукових цілей (Страсбург, 1986), норм біомедичної етики та відповідних Законів України. Комісією з біоетики Тернопільсько- 
Огляди літератури, оригінальні дослідження, погляд на проблему, випадок з практики, короткі повідомлення го національного медичного університету імені І. Я. Горбачевського МОЗ України порушень цих принципів не виявлено (протокол засідання № 62 від 11 січня 2021 року).

Морфологічні дослідження проведені спільно з працівниками морфологічного сектора Міжкафедральної навчально-дослідної лабораторії (зав. сектором - проф. Небесна 3. М.).

Результати й обговорення. При гістологічному дослідженні тканин пародонта інтактних білих щурів виявлено, що слизова оболонка представлена багатошаровим плоским зроговілим епітелієм. Цей факт свідчив про характерну видову відмінність слизової оболонки порожнини рота щурів.

Корені зубів кріпляться до комірок альвеолярного відростка за допомогою щільно зрощених з цементом кореня сполучнотканинних волокон періодонтальної зв'язки. Біля краю зубної альвеоли періодонт переходив у ясна. Між сполучнотканинними волокнами періодонта наявні нечисленні фібробласти, патологічних змін у судинах не виявлено (рис. 1).

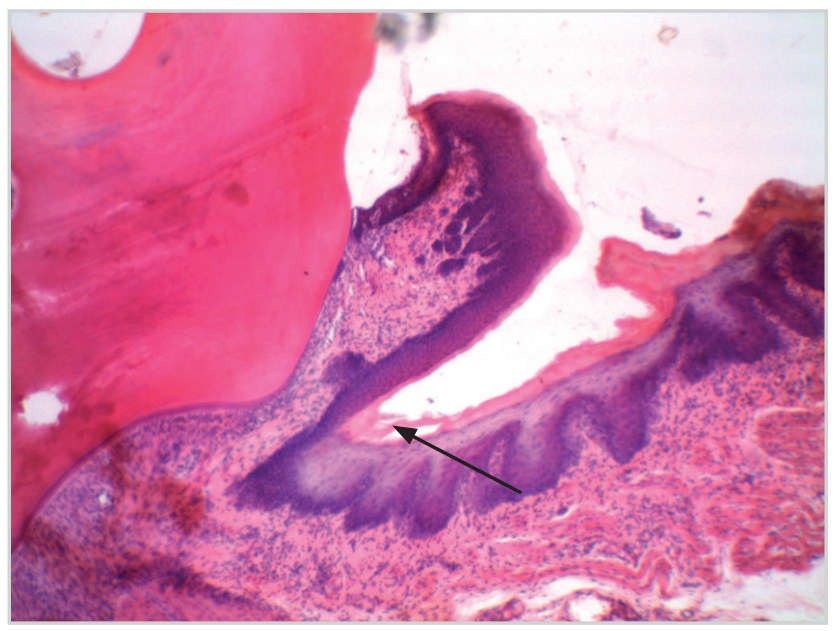

Рис. 1. Тканини пародонта інтактного щура контрольної групи. Широкий епітеліальний пласт. Капіляри інтактні, у власній пластинці наявна помірна клітинна інфільтрація. На слизовій оболонці перехідної складки (стрілка) помірні рогові маси. Гематоксилін і еозин $\times 40$.

Ясна між зубами були у вигляді вузького трикутника. Межа сполучної тканини й епітелію була рівною, у деяких ділянках сосочковий шар власної пластинки слизової оболонки утворював характерні вирости. Базальний шар представлений одним рядом клітин, характерною ознакою яких було розташування ядер на одному рівні (рис. 2).

Особливістю нормальної структури тканин пародонта щурів $\epsilon$ чітке пошарове розмежування епітелію, наявність невеликого зроговілого шару,

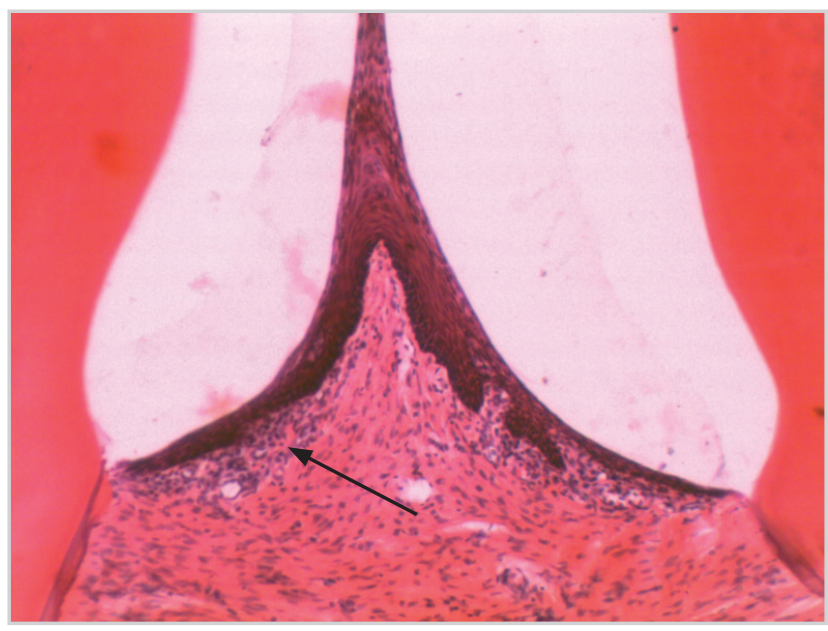

Рис. 2. Ясенний сосочок інтактного щура контрольної групи. Епітеліальний пласт вузький. Капіляри інтактні, помірна клітинна інфільтрація власної пластинки (стрілка). Гематоксилін і еозин × 100.

що $\epsilon$ ознакою ортокератозу. Такі морфологічні особливості обумовлені наявністю постійного функціонального навантаження гризунів під час харчування. Дані особливості будови тканин пародонта в інтактних щурів були потрібні для порівняння з такими за умови розвитку експериментального гінгівіту.

Викликання експериментальної патології підтверджувалося морфологічними змінами тканин пародонта у тварин усіх груп. У нормергічній групі міжклітинні простори між епітеліоцитами розширені. Епітелій інфільтрований лейкоцитами, серед яких переважали нейтрофіли (рис. 3).

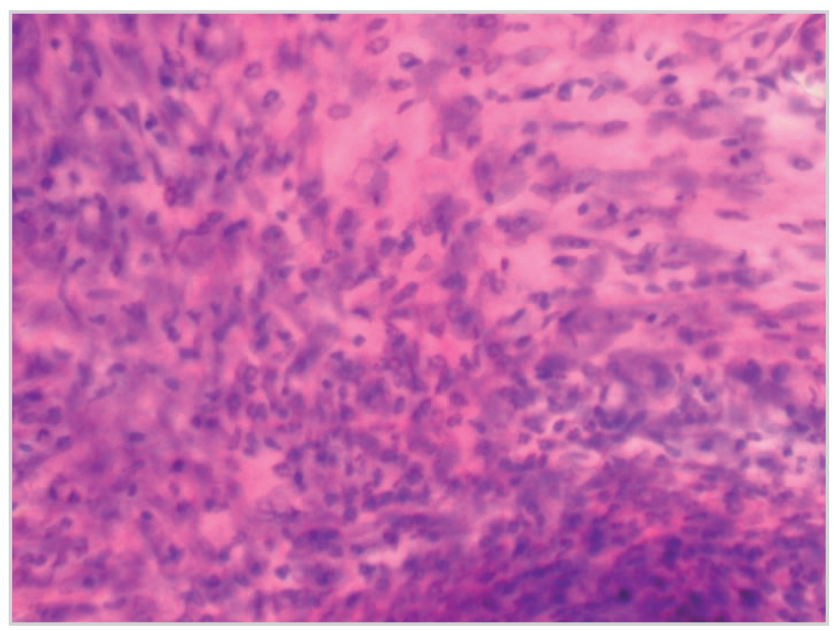

Рис. 3. Епітелій ясен нормергічного щура з експериментальним гінгівітом. Щільна лейкоцитарна інфільтрація у субепітеліальній ділянці. Гематоксилін і еозин $\times 250$.

Окрім того, лейкоцитарними елементами були інфільтровані і субепітеліальні тканини. Ясен- 
Огляди літератури, оригінальні дослідження, погляд на проблему, випадок з практики, короткі повідомлення ні сосочки були найбільш ураженими: спостерігали густу інфільтрацію нейтрофілами (рис. 4).

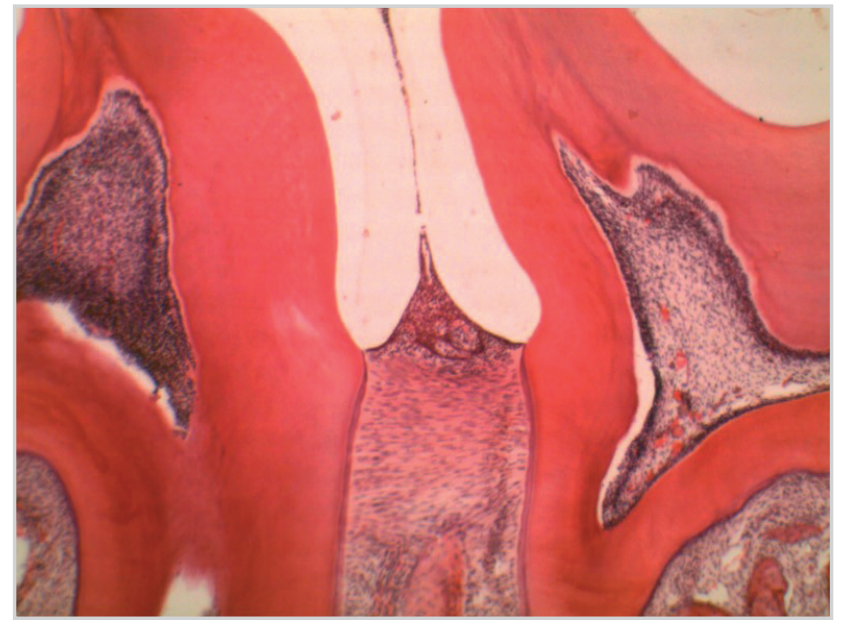

Рис. 4. Ясенний сосочок нормергічного щура з експериментальним гінгівітом. Інфільтрація та частковий некроз ясенного сосочка. Гематоксилін і еозин $\times 40$.

Морфологічна картина гінгівіту в гіпоергічній групі характеризувалась не тільки запальними змінами, одночасно з ними розвивалися дистрофічні і регенераторні процеси. Спостерігався виражений акантоз зі збільшенням епідермальних відростків (рис. 5), що є, найімовірніше, результатом уповільнення дозрівання та диференціювання епітеліоцитів унаслідок мітостатичної дії циклофосфаміду.

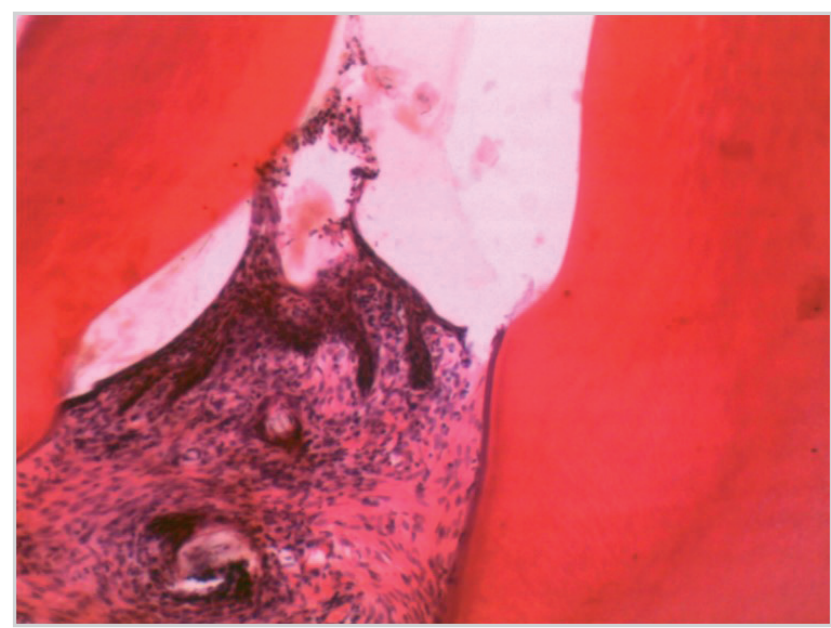

Рис. 5. Ясенний сосочок гіпоергічного щура з експериментальним гінгівітом. Масивний некроз ясенного сосочка, гнійні нашарування. Акантоз зі збільшенням епідермальних відростків. Гематоксилін і еозин $\times 40$.

Підтвердженням цього є мала кількість мітозів у клітинах базального шару. В епітелії міжзубних сосочків часто трапляються кістоподібні утворення з елементами ороговіння усередині (рис. 6).

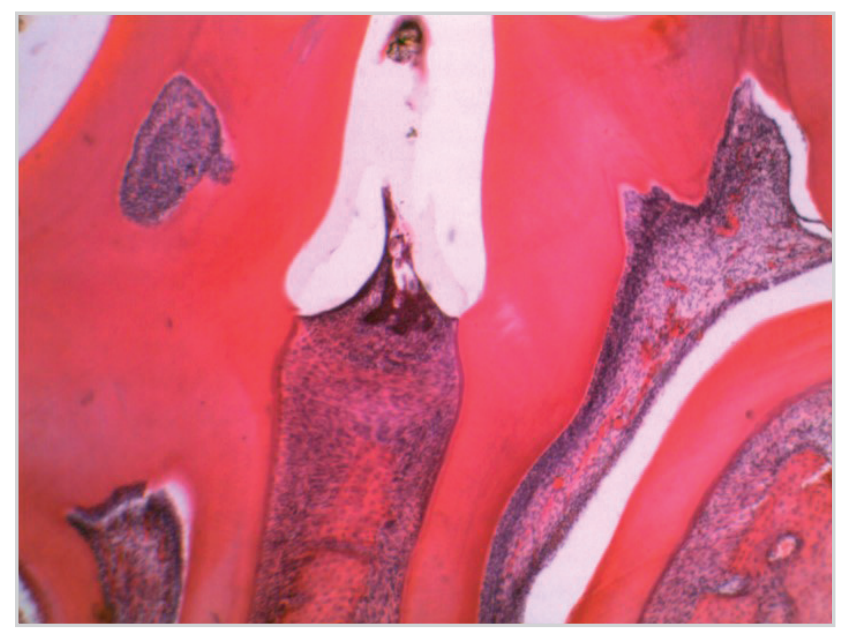

Рис. 6. Ясенний сосочок гіпоергічного щура з експериментальним гінгівітом. Ознаки ороговіння в епітелії міжзубного сосочка. Акантоз зі збільшенням епідермальних відростків. Гематоксилін і еозин × 40 .

Зустрічався паракератоз - порушення процесу ороговіння, коли зернистий шар практично відсутній, а в роговому визначаються клітини з пікнотичними паличкоподібними ядрами (рис. 7).

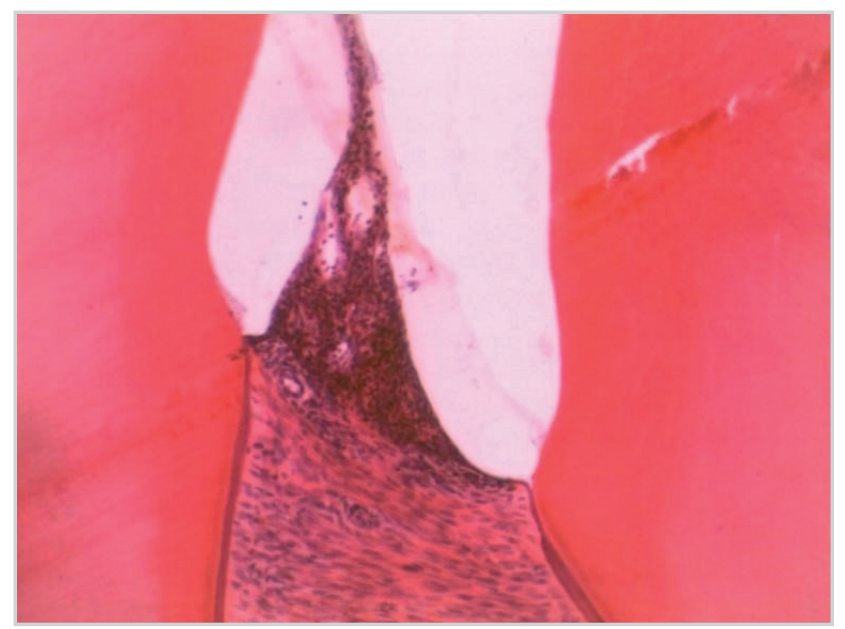

Рис. 7. Ясенний сосочок гіпоергічного щура з експериментальним гінгівітом. Ознаки паракератозу. Гематоксилін і еозин $\times 40$.

Висновки. Морфологічними дослідженнями встановлено, що при експериментальному гінгівіті без зміни реактивності організму були наявними деструктивні зміни епітеліального та сполучнотканинного шарів слизової оболонки ясен: набряк, лейкоцитарна інфільтрація у сполучнотканинному шарі; ущільнювалися зернистий та остистий шари епітелію.

Особливістю запального процесу в яснах при його гіпоергічному перебігу була лейкоцитарна інфільтрація як епітелію, так і субепітеліальних 
Огляди літератури, оригінальні дослідження, погляд на проблему, випадок з практики, короткі повідомлення тканин, поява акантозу зі збільшенням епідермальних відростків і паракератозу.

Перспективи подальших досліджень полягають у проведенні досліджень щодо ефективності різних коригуючих впливів на експериментальний гінгівіт.

\title{
ЛІТЕРАТУРА
}

1. Древніцька Р. О. Вплив лікувальних заходів на клінічно-лабораторні показники пацієнтів з гінгівітом при різному перебігу запального процесу в яснах / Р. О. Древніцька // Клінічна стоматологія. - 2020. № 4. - C. 49-56.

2. Morphological and functional characteristics of human gingival junctional epithelium / Qian Jiang, Youcheng Yu, Hong Ruan [et al.] // BMC Oral Health. - 2014. - Vol.14. Morphological and functional characteristics of human gingival junctional epithelium | BMC Oral Health | Full Text (biomedcentral.com).

3. Авдеев А. В. Изменения показателей перекисного окисления липидов и антиоксидантной системы В сыворотке крови у животных с экспериментальным па-

родонтитом при измененной реактивности / А. В. Авдеев, А. Б. Бойкив, Р. А. Древницкая // Georgian medical news. - 2019. - № 2 (287). - C. 124-127.

4. Патент на корисну модель № 146656 Україна МПK G09B 23/28 (2006/01). Спосіб моделювання гінгівіту з гіпоергічним перебігом запальної реакції. Древніцька Р. О., Авдєєв О. В., Бойків А. Б.; заявник і власник патенту Тернопільський національний медичний університет ім. І. Я. Горбачевського. - № u202005764; заявл. 07.09.2020; опубл. 10.03.2021, Бюл. № 10/2021.

5. Патоморфологія та гістологія / за ред. Д. Д. Зербіно, М. М. Багрія, Я. Я. Боднара, В. А. Діброви. - Вінниця : Нова книга, 2014. -805 с.

\section{REFERENCES}

1. Drevnitska, R.O. (2020). Vplyv likuvalnykh zakhodiv na klinichno-laboratorni pokaznyky patsiyentiv z hinhivitom pry riznomu perebihu zapalnoho protsesu v yasnakh [Influence of therapeutic measures on clinical and laboratory parameters of patients with gingivitis with different course of the inflammatory process in the gums]. Klinichna stomatolohiia - Clinical Dentistry, (4), 49-56 [in Ukrainian].

2. Qian Jiang, Youcheng Yu, Hong Ruan, Yin Luo \& Xuehua Guo (2014). Morphological and functional characteristics of human gingival junctional epithelium BMC Oral Health, 14, 30. (Morphological and functional characteristics of human gingival junctional epithelium | BMC Oral Health | Full Text (biomedcentral.com).

3. Avdieiev, O.V., Boikiv, A.B., \& Drevnitska, R.O. (2019). Izmeneniya pokazateley perekisnogo okisleniya lipidov i antioksidantnoy sistemy v syvorotke krovi u zhivotnykh s eksperimentalnym parodontitom pri izmenennoy reaktivnosti [Changes in indicators of lipid peroxidation and antioxidant system in blood serum in animals with experi-

mental periodontitis with altered reactivity]. Georgian Medical News, (2), 124-127 [in Russian].

4. Drevnitska, R.O., Avdieiev, O.V., \& Boikiv, A.B. Patent na korysnu model № 146656 Ukraina MPK G09B 23/28 (2006/01) [Utility model patent No. 146656 Ukraine G09B 23/28 (2006/01)]. Sposib modelyuvannya hinhivitu z hipoerhichnym perebihom zapalnoyi reaktsiyi [A method of modeling gingivitis with a hypoergic course of the inflammatory reaction]. Zaiavnyk i vlasnyk patentu Ternopilskyi natsionalnyi medychnyi universytet im. I. Ya. Horbachevskoho. № U202005764; zayavl. 07.09.2020; opubl. 10.03.2021, Bul. № 10/2021. - Applicant and patent holder I. Horbachevsky Ternopil National Medical University. - No. 202005764; stated 07.09.2020; published 10.03.2021, Bulletin No. 10/2021 [in Ukrainian].

5. Zerbino, D.D., Bahriy, M.M., Bodnar, Ya.Ya. \& Dibrov, V.A. (2014). Patomorfolohiya ta histolohiya [Pathomorphology and histology]. Vinnytsya : Nova knyha [in Ukrainian].

\section{MORPHOLOGICAL CHANGES IN EXPERIMENTAL GINGIVITIS WITH HYPOERGIC COURSE OF THE INFLAMMATORY PROCESS}

\author{
@R. O. Drevnitska, Z. M. Nebesna, O. V. Avdeev, A. B. Boykiv, B. O. Avdeev \\ I. Horbachevsky Ternopil National Medical University
}

SUMMARY. The aim - to investigate the morphological changes of periodontal tissues in experimental gingivitis with a hypoergic course of the inflammatory process.

Material and Methods. Histological examination was performed on the alveolar process with teeth and periodontal tissues of intact rats and rats with experimental gingivitis. Sections 6-7 $\mu \mathrm{m}$ thick were made, which were stained with hematoxylin and eosin. 
Огляди літератури, оригінальні дослідження, погляд на проблему, випадок з практики, короткі повідомлення

Results. The morphological picture of gingivitis in the hypoergic group was characterized not only by inflammatory changes, at the same time dystrophic and regenerative processes develop. There is a pronounced acanthosis with enlargement of the epidermal processes, which is most likely the result of slowing maturation and differentiation of epitheliocytes due to the mitostatic action of cyclophosphamide.

This is confirmed by the small number of mitoses in the cells of the basal layer. In the epithelium of the interdental papillae are often cystic formations with elements of keratinization inside.

There was parakeratosis - a violation of the keratinization process when the granular layer is almost absent, and in the horny cells with pyknotic rod-shaped nuclei are identified.

Conclusions. Morphological studies have shown that in experimental gingivitis without changes in the reactivity of the organism there were destructive changes in the epithelial and connective tissue layers of the gingival mucosa; edema, leukocyte infiltration in the connective tissue layer, compacted granular and spinous layers of the epithelium.

The peculiarity of the inflammatory process in the gums during its hypoergic course was leukocyte infiltration of both epithelium and subepithelial tissues, the appearance of acanthosis, with an increase in epidermal processes, and parakeratosis.

KEY WORDS: gingivitis; the course of the inflammatory reaction; structural changes of the gums.

Отримано 14.09.2021 